\title{
The Impact of Climate Change on the Reliability of Water Resources
}

\author{
Vojtěch Sýs *(D), Pavel Fošumpaur (D) and Tomáš Kašpar (D) \\ Faculty of Civil Engineering, Czech Technical University in Prague, Thákurova 7, \\ 16629 Prague 6, Czech Republic; fosumpaur@fsv.cvut.cz (P.F.); tomas.kaspar@cvut.cz (T.K.) \\ * Correspondence: vojtech.sys@fsv.cvut.cz; Tel.: +420-723-560-164
}

Citation: Sýs, V.; Fošumpaur, P.; Kašpar, T. The Impact of Climate Change on the Reliability of Water Resources. Climate 2021, 9, 153. https://doi.org/10.3390/ cli9110153

Academic Editors: Ondrej Ledvinka, Josef Křeček, Anna Lamacova and Adam Kertesz

Received: 3 September 2021

Accepted: 18 October 2021

Published: 21 October 2021

Publisher's Note: MDPI stays neutral with regard to jurisdictional claims in published maps and institutional affiliations.

Copyright: (C) 2021 by the authors. Licensee MDPI, Basel, Switzerland. This article is an open access article distributed under the terms and conditions of the Creative Commons Attribution (CC BY) license (https:/ / creativecommons.org/licenses/by/ $4.0 /)$.

\begin{abstract}
Climate change impact assessment is crucial for strategic planning in many areas, including water management, agriculture and forestry. Water planning has a long tradition in the Czech Republic, who has implemented the requirements of the Water Framework Directive since 2000. Following the expected impacts of climate change on the hydrological regime, adaptation measures in the water sector are being prepared as part of strategic plans. This contribution studies the uncertainty propagation of climate scenarios in hydrological data, which are then used to assess the reliability of water resources and to design appropriate adaptation measures. The results are being discussed for a case study in the deficit area of Rakovnický stream and Blšanska river basins, which are among the driest areas in the Czech Republic. Research of the impact of climate change on the reliability of water resources has been prepared using ensembles of selected regional climate models. This approach has allowed a probabilistic assessment of the impact on the hydrology regime and the reliability of water supply from reservoirs for various time horizons of climate change. In view of the relatively large variance of potential impacts on water resources, options for further strategic planning in the water management area are being discussed.
\end{abstract}

Keywords: climate change; water resources; reliability; uncertainty; climate models; Czech Republic; Kryry reservoir

\section{Introduction}

The stationarity of natural phenomena in river basins has been negatively affected by human activities for a prolonged period of time and cannot, due to ongoing hydroclimatic changes, be considered as the baseline assumption for the design and management of water resources. Changes in meteorological and hydrological parameters due to climate change are statistically significant [1]. Climate change generally leads to changes in the spatial and time distribution of precipitation and changes to its overall balance, increased probability of extreme phenomena (floods and droughts) and rises in average air temperatures [1-3].

From the hydrological point of view, climate change results in lower natural accessibility of water (a drop in groundwater levels and rate of streamflows). Ongoing changes to our climate, however, do not impact only the areas of climatology and hydrology, but are also reflected in the area of water management where they directly affect the reliability of water resources and availability of water supplies from water reservoirs. Water reservoirs allow water accumulation in active storage capacity, and thus, ensure the availability of water for people, agriculture and industry. Climate change, therefore, directly affects the lives of people all over the world. Reservoirs also have a significant environmental function, as they can be used to ensure environmentally safe flow rates in watercourses during dry periods [4]. Based on the nature of water management systems of water reservoirs, these systems may represent a robust tool for compensation of the impacts of climate change, provided that a reliable prediction of the development of climate phenomena is available.

The Council of the European Union has been dealing with topics such as lack of water, drought and adaptation to climate change since 2005. In 2010, the Environment Council 
accepted conclusions that support the activities of member states to reduce the vulnerability of the EU towards the impacts of climate change in all of its aspects, and asks member states to prepare plans for handling drought and dry periods and to promote sustainable water management [5]. In the Czech Republic, planning of surface water accumulation already dates back to the beginning of the 20th century. The first consistent overview of the utilization options for water resources in the Czech Republic was the Czechoslovak State Water Management plan processed between 1949 and 1953. This plan was gradually updated and completed, and in 1975, it contained over 500 survey locations of potential reservoirs with 286 locations being recommended for territorial protection. In 2005-2007, the Plan of Main River Basins in the Czech Republic was created as a long-term concept for water management and was based on 186 protected locations from the 1980s. Following up on the Plan of Main River Basins of the Czech Republic, the so-called General Plan of protected localities for surface water accumulation (LASW), was created in 2011. LASW originally contained a set of 65 locations divided into two categories. The first category (21 locations) consisted of areas whose water management significance lies namely in their ability to create or supply drinking water resources. The second category (44 locations) consisted of areas suitable for accumulation as a means of flood protection, for covering water supply demands and for the improvement of low flows.

Between 2014 and 2020, Central Europe was affected by an extreme hydrological drought [6] that resulted in the need to reassess the strategy of adopted measures in the Czech Republic. In reaction to climate change, 21 locations with emphasis on areas that are most threatened by water scarcity were added to LASW in 2020. Profiles of these planned reservoirs are protected to allow possible future development of water resources in case of unfavorable impacts of climate change on water supply and flood protection [5]. LASW also included the creation of estimated future balances for individual locations. As a consequence, national research institutions (Czech Globe, T. G. Masaryk Water Research Institute, p.r.i.) have prepared a number of climate scenarios for individual locations.

LASW is one of the water planning tools used in the Czech Republic. Since 2000, European Directives related to water management have been implemented into the legislature of individual European Union (EU) member states. The Water Framework Directive 2000/60/EC and Floods Directive 2007/60/EC are also gradually being implemented. In the Czech Republic, measures are proposed on the level of individual river basins and on the level of national plans (Danube river basin; Elbe river basin; Oder river basin). In relation to the expected impact of climate change on the hydrological regime of water courses, strategic plans also incorporate adaptation measure for the water management sector.

The proposed adaptation measures depend on the prediction of potential climate change impacts on the hydrological regime of water courses, using predominantly topdown (scenario-led) methods that start with the expected societal development towards proposed adaptation methods. These methods use the outputs of the Atmosphere-Ocean General Circulation Models (AOGCMs) that describe the energy exchange processes between the atmosphere and oceans, or the outputs of the Regional Climate Models (RCMs) that are often nested in Global Circulation Models (GCMs) [7]. This approach is based on the construction of climate scenarios and assessment of impacts on hydrological processes using hydrological models. The impacts of climate change on water balance and possible adaptation measures have been studied, for example, by Beran et al. [8].

The majority of research on this approach for finding adaptation measures ends merely with an assessment of the impacts of climate change, and usually does not continue to the identification of possible adaptation measures. Modeling of climate change impacts on hydrology and water resources using climate models is burdened by the high uncertainty of outputs, which increases with every additional step.

The initial source of uncertainty is the selection of the control emission scenarioSpecial Report on Emissions Scenarios (SRES) or Representative Concentration Pathways (RCP) $[9,10]$ - which stipulate the estimated development of the amount of greenhouse gases in the atmosphere based on the prediction of the social and economic development of 
society and the production of emissions. Other sources of uncertainty include the structure of the GCM and lack of more detailed information (scale of the model-hundreds of kilometers) [11]. The demand for more detailed information worldwide caused a certain pressure to develop RCMs that reduce these uncertainties, at least to a degree. Past studies have shown that uncertainty caused by RCMs is significantly lower than the uncertainty stemming from AOGCMs, which are the largest source of uncertainty $[7,12,13]$. Selection of the GCM simultaneously has a greater impact on hydrological changes than the selection of the emission scenario [12]. So-called downscaling methods have been developed to provide prediction on a finer scale $[10,11]$, but even the ability to transfer this information using Regional Climate Downscaling (RCD) to a more detailed time and spatial scale does not result in a high reliability of the results, as even the RCD method is significantly limited by available meteorological data and their quality [14].

This study investigates the impacts of climate change on hydrological data and the reliability of water resources. It focuses on drawing attention to the great variance of possible impacts on water resources using climate models, which makes the strategic planning of water resources very difficult. The propagation of uncertainty of climate scenarios into the hydrological regime and water management balance of reservoirs is significant. This study evaluates (1) the impact of uncertainty of climate models on the variability of future climate variables; (2) how significantly these predictions of climate change affect the variability of hydrological data; and (3) their impact on the reliability of water resources. The issue of uncertainty of climate scenarios using top-down methods is demonstrated in the case study of strengthening the water resources in the deficit river basin of the Rakovník stream and the Blšanka river, which are among the driest areas in the Czech Republic.

\section{Materials and Methods}

\subsection{Study Area}

As a Central European country, the Czech Republic is less exposed to drought than regions in the south of Europe [15], but in spite of this, the Czech Republic contains locations which have a significant risk of drought. This is caused predominantly by the significant spatial variability of precipitation, which is one of the primary factors affecting the occurrence of drought. Annual precipitation in the Czech Republic ranges between approximately $450 \mathrm{~mm}$ in the driest areas and over $1500 \mathrm{~mm}$ in mountainous areas [16].

The river basin of the Rakovník stream and the Blšanka river is located in Western Bohemia (Figure 1) and is among the driest areas in the Czech Republic, one with a significant water deficit in the most recent hydrologically deficient years. Figure 2 shows the graphs of annual air temperatures and precipitations for the studied catchment at the Stránky gauge station. These graphs clearly demonstrate the evolution of basic climate variables over the observation period (1961-2016). The course of air temperatures shows a gradual warming with an average gradient of $0.035\left({ }^{\circ} \mathrm{C} /\right.$ year $)$, while no systematic trend is evident in the course of annual precipitation. Study area is currently being intensively used for agriculture, especially for the growing of hops. This is why the construction of new reservoirs is being planned, notably Šanov and Senomaty in the basin of the Rakovník stream and the Kryry reservoir in the basin of the Blšanka river. The key element of this planned water system will be the Kryry reservoir, with a water retention capacity of 7,000,000 $\mathrm{m}^{3}$ [6]. The Kryry reservoir basin area is $86 \mathrm{~km}^{2}$ and its average flow is $0.17 \mathrm{~m}^{3} \cdot \mathrm{s}^{-1}$. The Kryry reservoir will be used not only for the accumulation of water in the Blšanka river basin, but will also strengthen the water balance for the planned Senomaty and Šanov reservoirs in the Rakovník stream basin via water transfer (the solid green line in Figure 1). In view of the significant uncertainty in the available climate scenarios, the transfer of water from the Ohře river (green dotted line in Figure 1) is also planned. This measure will strengthen the system in case of a more pessimistic development of climate change. 


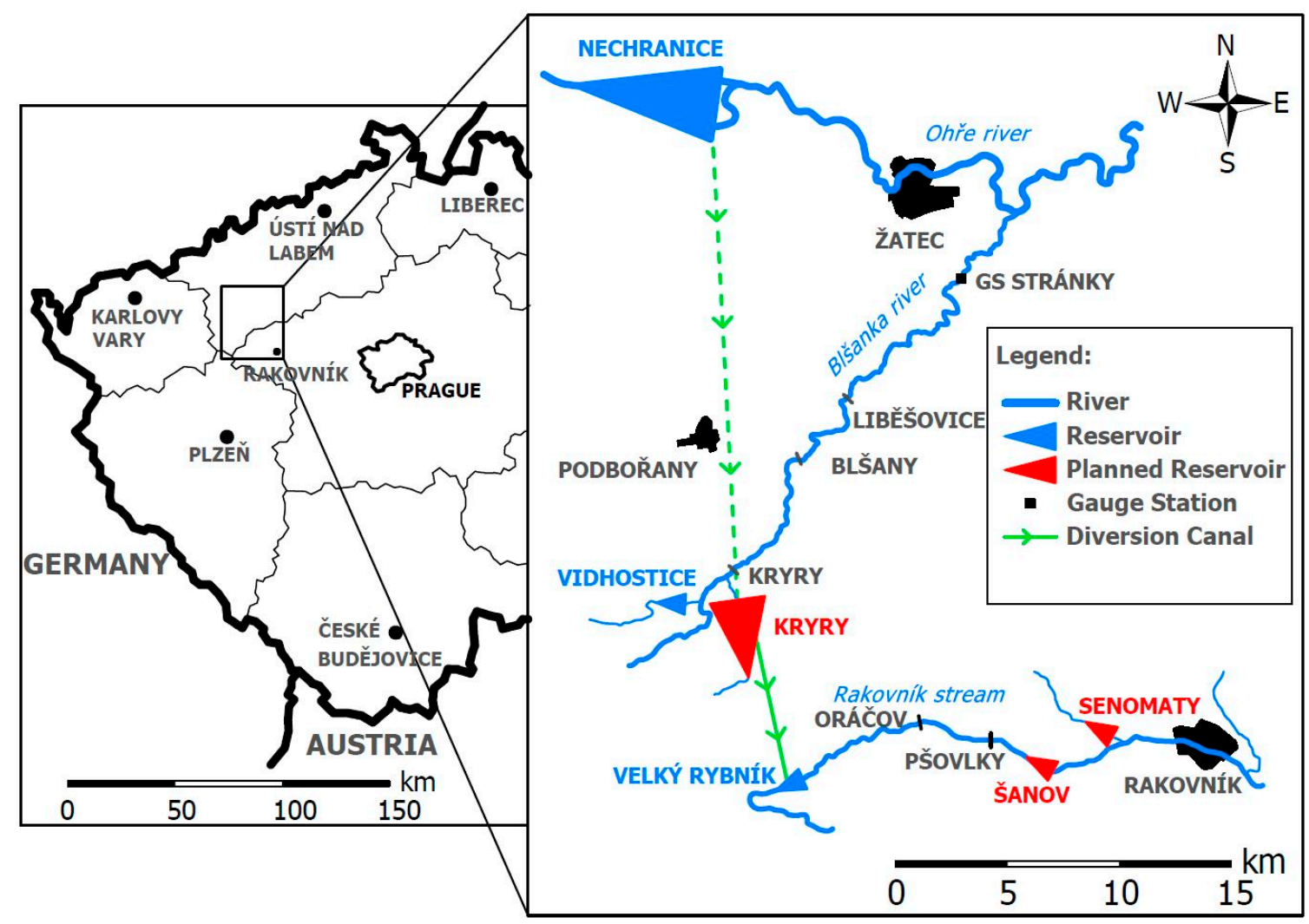

Figure 1. Map of the study area in the Czech Republic.

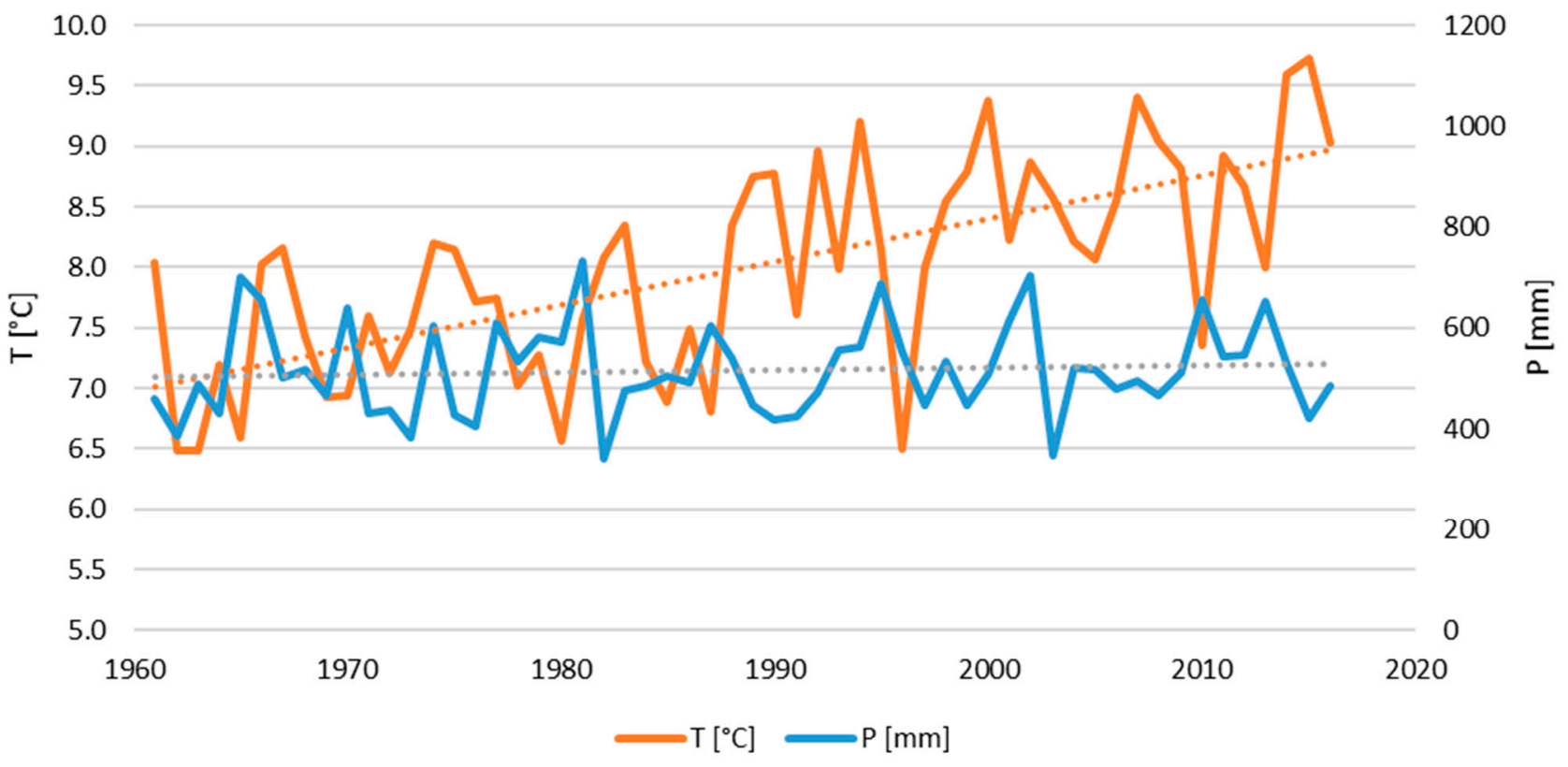

Figure 2. Current climate conditions for the GS Stránky—observed yearly temperatures and precipitations.

\subsection{Current Climate Conditions}

The current climate conditions are represented by the observed time series of river flows, air temperatures and precipitation values in the profile of the planned Kryry reservoir in the Blšanka river basin. Each step in these series represents one month and the series cover the period of 1961-2016. The flow series were obtained via the hydrological analogy method based on data from the Stránky gauge station downstream of the Blšanka river 
(Figure 1). In this study, the monthly step of the flow time series is sufficient to compute the required storage volume of the planned Kryry reservoir.

\subsection{Climate Change Scenarios}

Perhaps the most frequently used models for proposing new water resources are climate change models for the mid-term future that are based on greenhouse gas emission scenarios. This procedure was also used for the water management solution of the planned Kryry reservoir. The hydrological balance was modeled using three sources of information (Table 1):

1. Global climate models from the CMIP5 project (Climate Intercomparison Project), which were also used for the Fifth Assessment Report of the IPCC. The scenarios RCP2.6, RCP4.5 and RCP8.5 were used for the models. Fifteen combinations of global models were used in total.

2. Regional climate models from the ENSEMBLES project [17]. The SRES A1B scenario was selected for simulations. Fourteen regional models were used in total.

3. Regional climate models from the CORDEX (Coordinated Regional Climate Downscaling Experiment) project [18]. The RCP4.5 concentration model was selected along with five global models with regional downscaling. Research within the CORDEX project has not been completed yet.

Table 1. Used climate models.

\begin{tabular}{|c|c|c|c|c|}
\hline \multicolumn{5}{|c|}{ CMIP5 Project } \\
\hline GCM & RCM & Source & Grid & Forcing \\
\hline BNU-ESM & & Beijing Normal University & $2.791^{\circ} \times 2.813^{\circ}$ & \\
\hline CNRM-CM5 & & National Centre of Meteorological Research, France & $1.401^{\circ} \times 1.406^{\circ}$ & \\
\hline HadGEM2-ES & & Met Office Hadley Centre, UK & $1.250^{\circ} \times 1.875^{\circ}$ & RCP2.6, RCP4.5, \\
\hline IPSL-CM5B-LR & & Institut Pierre Simon Laplace, France & $1.895^{\circ} \times 3.750^{\circ}$ & RCP8.5 \\
\hline MRI-CGCM3 & & Meteorological Research Institute, Japan & $1.121^{\circ} \times 1.125^{\circ}$ & \\
\hline \multicolumn{5}{|c|}{ CORDEX Project } \\
\hline GCM & RCM & Source & Grid & Forcing \\
\hline CNRM-CM5 & ALADIN53 & National Centre of Meteorological Research, France & & \\
\hline EC-EARTH & RACMO22E & Royal Netherlands Meteorological Institute & & \\
\hline IPSL-CM5A-MR & RCA4 & National Centre of Meteorological Research, France & $12 \mathrm{~km} \times 12 \mathrm{~km}$ & RCP4.5 \\
\hline HadGEM2-ES & RCA4 & National Centre of Meteorological Research, France & & \\
\hline MPI-ESM-LR & CLMcom-CCLM4-8-17 & The Climate Limited-area Modeling Community & & \\
\hline \multicolumn{5}{|c|}{ Ensemble Project } \\
\hline GCM & RCM & Source & Grid & Forcing \\
\hline ARPEGE4.5 & ALADIN-CLIMATE & Czech Hydrometeorological Institute, Czech Republic & & \\
\hline HadCM3Q0 & CLM2.4.6 & Swiss Federal Institute of Technology Zurich & & \\
\hline ARPEGE4.5 & CNRM-RM5.1 & National Centre of Meteorological Research, France & & \\
\hline ARPEGE4.5 & HIRHAM5 & Danish Meteorological Institute & & \\
\hline ECHAM5 & HIRHAM5 & Danish Meteorological Institute & & \\
\hline HadCM3Q0 & HadRM3.0 & Met Office Hadley Centre, UK & & \\
\hline HadCM3Q3 & HadRM3.0 & Met Office Hadley Centre, UK & & \\
\hline HadCM3Q16 & HadRM3.0 & Met Office Hadley Centre, UK & $25 \mathrm{~km} \times 25 \mathrm{~km}$ & SRES A1B \\
\hline ECHAM5 & RACMO2.1 & Royal Netherlands Meteorological Institute & & \\
\hline ECHAM5 & RCA3.0 & Swedish Meteorological and Hydrological Institute & & \\
\hline HadCM3Q16 & RCA3.0 & Swedish Meteorological and Hydrological Institute & & \\
\hline HadCM3Q3 & RCA3.0 & Swedish Meteorological and Hydrological Institute & & \\
\hline ECHAM5 & REMO5.7 & Max Planck Institute for Meteorology, Germany & & \\
\hline ECHAM5 & RegCM3 & $\begin{array}{c}\text { Abdus Salam International Centre for Theoretical } \\
\text { Physics, Italy }\end{array}$ & & \\
\hline
\end{tabular}

The global climate models were selected based on the recommendations of the Global Change Research Institute of the Czech Academy of Sciences (GCRI) [19]. These climate models were evaluated as appropriate for the Czech Republic and Central Europe region. Regional climate models were selected based on the conclusions of similar studies in the 
Czech Republic [8,20-22]. The control period was set to 1981-2010 and scenarios were created for the following periods: 2021-2040, 2041-2060, and 2081-2100.

All simulated scenarios have been developed by the simple delta change method [22,23]. The core idea of the method is based on the calculation of change factors, which quantify the average changes in precipitation and air temperature for each calendar month. The change factors are quantified based on climate model simulations for the control (in our case, 1981-2010) and scenario periods. The obtained change factors are used to adjust the observed series. Precipitation values are transformed multiplicatively, while temperature is transformed additively [24]. Change factors for the study catchment are obtained using change factors calculated from grid boxes of the climate model intersecting the catchment area as an average weighted by the inverse distance between a grid box and the center of the catchment. This is a relatively robust method for scenario construction and removes systematic errors in the climate models. It is sometimes recommended to use more advanced methods for creating climate change scenarios for very long sequences and with the aim of assessing long-term variability; such advanced methods also take into account more long-term changes. However, the differences are often not very significant.

\subsection{Hydrological Model and Modeling of Hydrological Balance Changes}

Hydrological balance modeling was carried out using the BILAN hydrological model [25]. This is a conceptual model that can consider daily or monthly time steps. The model simulates the basic balance relations on the surface of the basin; in the aeration zone, which also includes the vegetation cover of the basin; and in the underground water zone. A description of the model was published, e.g., by Tallaksen and van Lanen [26]. The input data are the time series for the precipitation and air temperatures and the model is calibrated based on the observed outflow. The monthly version of the model is controlled using eight free parameters. The outputs of the model are: potential evapotranspiration, ground evaporation, infiltration into the aeration zone, seepage through this zone, water retained in snow, water retained in soil and underground water retention. The correction of systematic errors was handled for basin outflow in the same way as for climate models using the delta change method. This means that in the first phase, the BILAN hydrological model needs to be calibrated using the observed outflow in the outlet profile of the basin. This is followed by a simulation of the hydrological balance for the selected scenario periods with the use of the above-described set of climate models and emission scenarios. The change factors are then computed as changes between the runoff series corresponding to the control and scenario periods calculated for each month. The resulting flow series are then obtained by modifying the observed data for the control period using change factors for individual months. This approach removes the influence of systematic errors of the hydrological model on scenario simulations.

\subsection{Reliability and Storage-Yield Relationship}

The storage-yield (S-Y) relationship is used to assess the propagation of uncertainty in the estimated parameters of climate change scenarios into the reliability of water supply from the Kryry reservoir in the Blšanka river basin. S-Y describes the dependence of the required storage capacity on the required yield for the given reliability. The required reservoir volume is calculated using a balance equation for the reservoir in each monthly step [27]:

$$
S_{t}=\max \left[0, \min \left(S_{t-1}+X_{t}-D_{t}, c\right)\right]
$$

where $S_{t}$ is the volume of water in the reservoir at the end of step $t\left(\mathrm{~m}^{3}\right) ; S_{t-1}$ is the volume of water in the reservoir at the end of step $t-1\left(\mathrm{~m}^{3}\right) ; X_{t}$ is the flow into the reservoir at step $t\left(\mathrm{~m}^{3}\right)$ adjusted for the evaporation loss from the water surface and precipitation reaching the surface; $D_{t}$ is the total demand at step $t\left(\mathrm{~m}^{3}\right) ; c$ is the reservoir capacity $\left(\mathrm{m}^{3}\right)$. The total reservoir release at step $t$ is given by the following equation:

$$
R_{t}=\min \left(S_{t-1}+X_{t}, D_{t}\right)
$$


The reservoir spill $\left(W_{t}\right)$ is then:

$$
W_{t}=S_{t-1}-S_{t}+X_{t}-R_{t}
$$

After simulating the behavior of a reservoir with the given reservoir capacity $c$ via a sequence of monthly flows, it is possible to determine the time-based reliability using the following relation:

$$
R=P\left(R_{t} \geq D_{t}\right)=\left(N-N_{\mathrm{f}}\right) / N
$$

The reliability of the reservoir is equal to the ratio between the number of monthly steps without a water supply defect and the total number $N$ of months in the flow sequence, where $N_{\mathrm{f}}$ is the number of months with a defect.

The S-Y relationship was computed for a time-based reliability of $R=98.5 \%$. Assuming a constant demand of $D$ (desired yield), we define the yield ratio as $\alpha=D / \mu$, where $\mu$ is the mean annual streamflow for the current climatic conditions. In order to separate the effect of climate change on reservoir capacity, the water demand was considered at the same level for the present and future time horizons. The water demand was treated as a variable in the interval from 0 to $0.85 \mu$. We define the storage ratio as $\beta=c / \mu$ and describe the average number of years required to fill the reservoir capacity. A value of $\beta>1$ indicates over-year reservoir control.

\section{Results}

The first task within the analysis was to assess the uncertainty of meteorological parameters and basin outflow for three selected climate change time horizons: 2021-2040, 2041-2060 and 2081-2100. The time series of basin outflow, air temperature and precipitation are related to the profile GS Stránky (catchment area is $380 \mathrm{~km}^{2}$ ). Air temperatures and precipitations are assumed to be the same for the Kryry profile (catchment area is $86 \mathrm{~km}^{2}$ ). The basin outflow in the Kryry profile was derived from the GS Stránky profile as a ratio of the catchment areas. The average outflow from the basin in the Stránky profile is $0.76 \mathrm{~m}^{3} \cdot \mathrm{s}^{-1}$ and, in the Kryry profile, $0.17 \mathrm{~m}^{3} \cdot \mathrm{s}^{-1}$. The assessment was prepared for air temperatures and precipitation in individual calendar months. All 34 climate models were used for the analysis in combination with the appropriate emission scenarios. The results of the analysis for monthly air temperatures are provided in Figure 3 and for monthly precipitation in Figure 4. The graphs always display the whole range (min-max) of the assessed change factors, the $90 \%$ confidence interval and the $50 \%$ confidence interval. For ease of navigation, the monthly values of the selected GCM from the CMIP5 project are marked in color for the RCP2.6, RCP4.5 and RCP8.5 emission scenarios. Air temperatures are assessed as an additive change $\mathrm{dT}\left({ }^{\circ}\right)$ and precipitation as a multiplicative change $\mathrm{dP}(-)$.

The air temperature change factors (Figure 3 ) indicate a growing trend for more distant time horizons. For the precipitation change factors (Figure 4), there is a fairly even annual balance with a clear tendency towards redistribution over the course of a year, where one can expect a reduction in precipitation in the summer and an increase in the winter. For both meteorological parameters, there is a clearly visible gradual variance of the estimated changes for more distant time horizons, demonstrating a high degree of uncertainty. This uncertainty also propagates into the estimated change of the hydrological balance, which is analyzed in Figure 5 via quantification of the multiplicate change factor of the outflow from the river basin, dQ (-). The results indicate that for the nearest time horizon of 2021-2040, the change factor $\mathrm{dQ}$ for individual calendar months oscillates between 0.5 and 2.0. In practice, this means that the outflow could be twice as large or small compared to the control period of 1981-2010, which represents current climate conditions. This uncertainty is also significantly increased in more distant time horizons. 

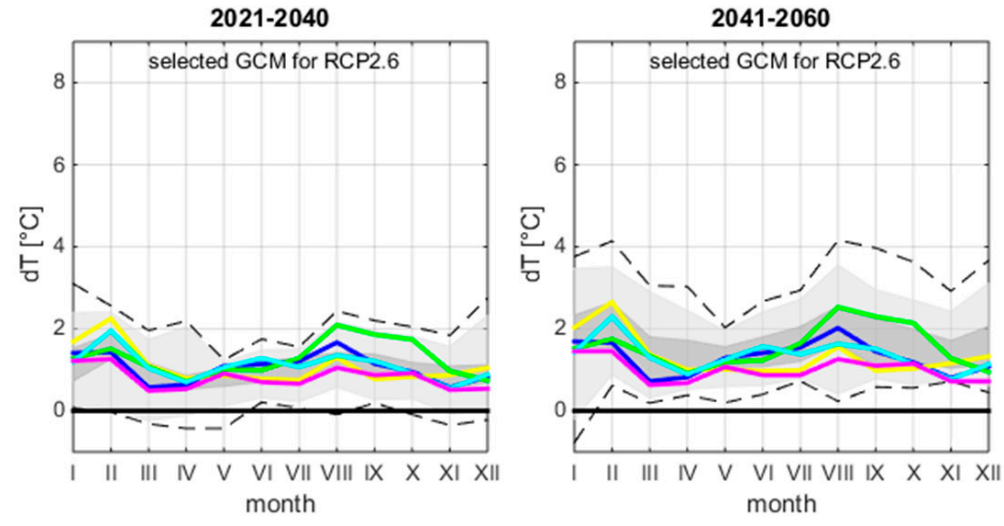

2021-2040
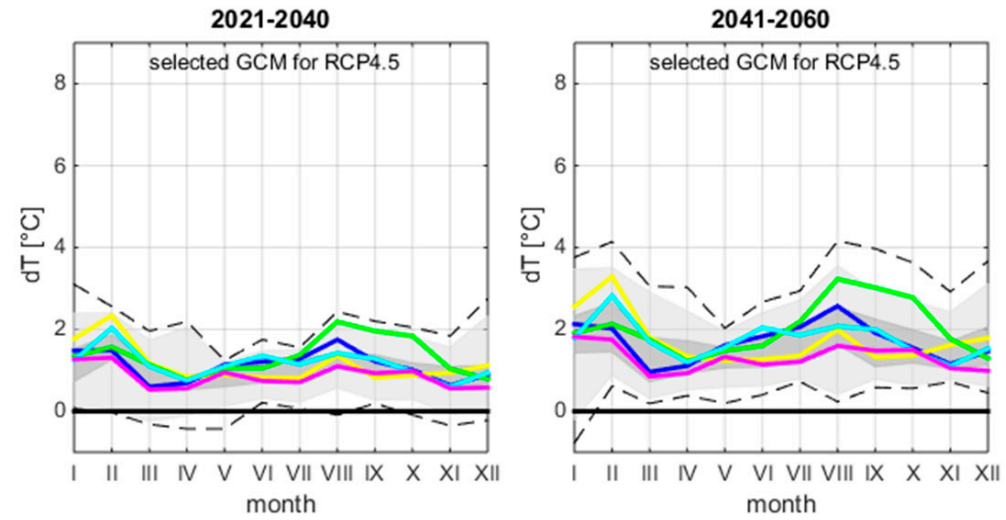

2021-2040

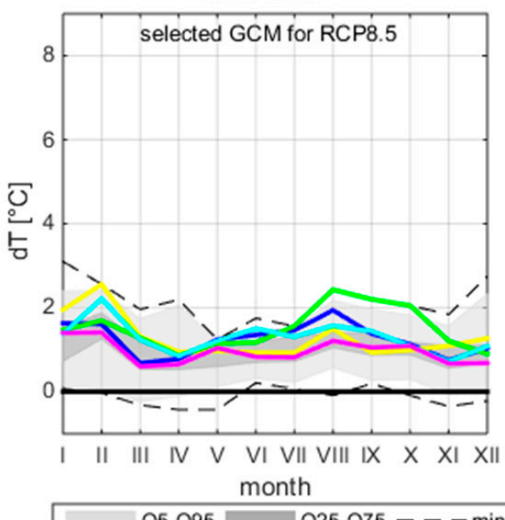

2041-2060

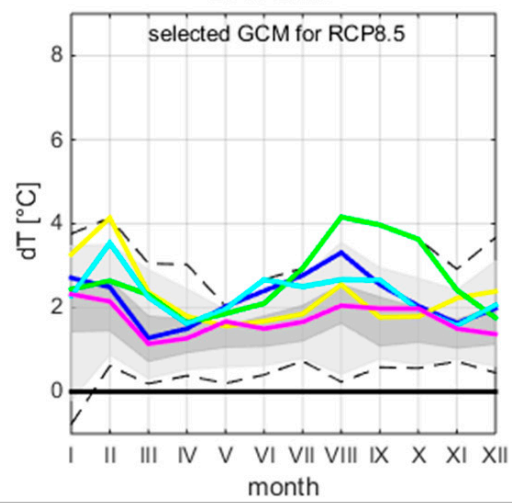

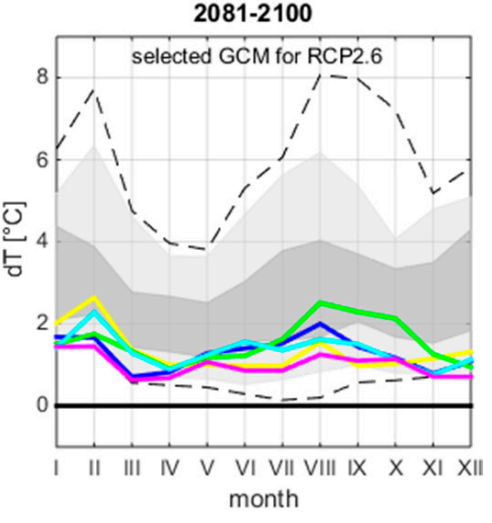

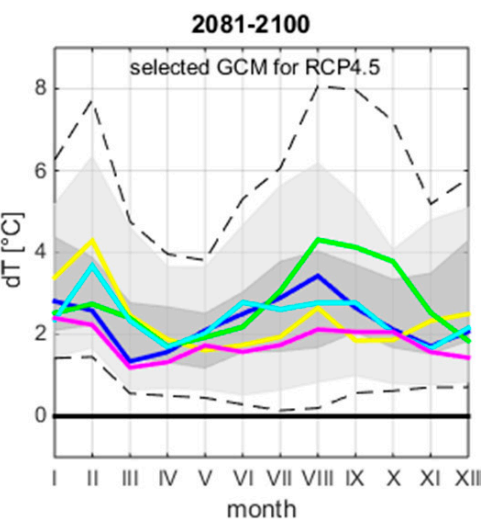

2081-2100

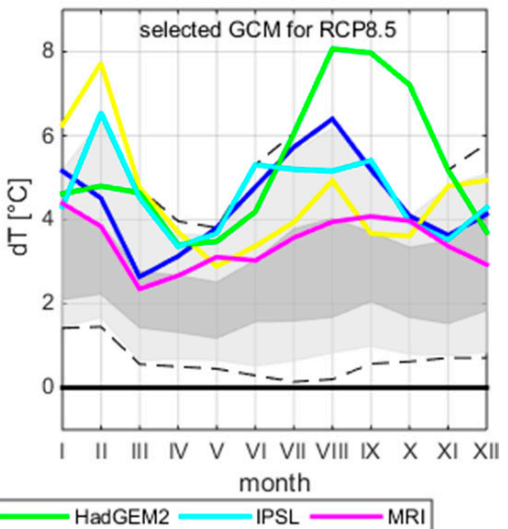

Figure 3. Uncertainty of the estimated monthly air temperatures for individual time horizons (columns). The 90\% (Q5-Q95) and 50\% (Q25-Q75) confidence intervals are calculated for the ensemble of all 34 model outputs. The GCM models from the CMIP5 model for selected RCP emission scenarios (rows) are marked in color.

The next analysis focused on evaluating the variance of mean annual flows for each time horizon. The result is shown in Figure 6 using boxplots of the change factors of the annual flows. The median of annual flow change factors dQ for the 2021-2040 time horizon is 1.00, indicating the same conditions as the 1981-2010 control period. The median for the 2061-2080 time horizon is 0.88 , indicating a $12 \%$ reduction in mean flow, and the median for the $2081-2100$ time horizon is 0.83 , indicating a $17 \%$ reduction in mean flow. The variance of the change factors increases significantly for more distant time horizons, indicating an increasing level of uncertainty in the estimate of the change in annual flows. 

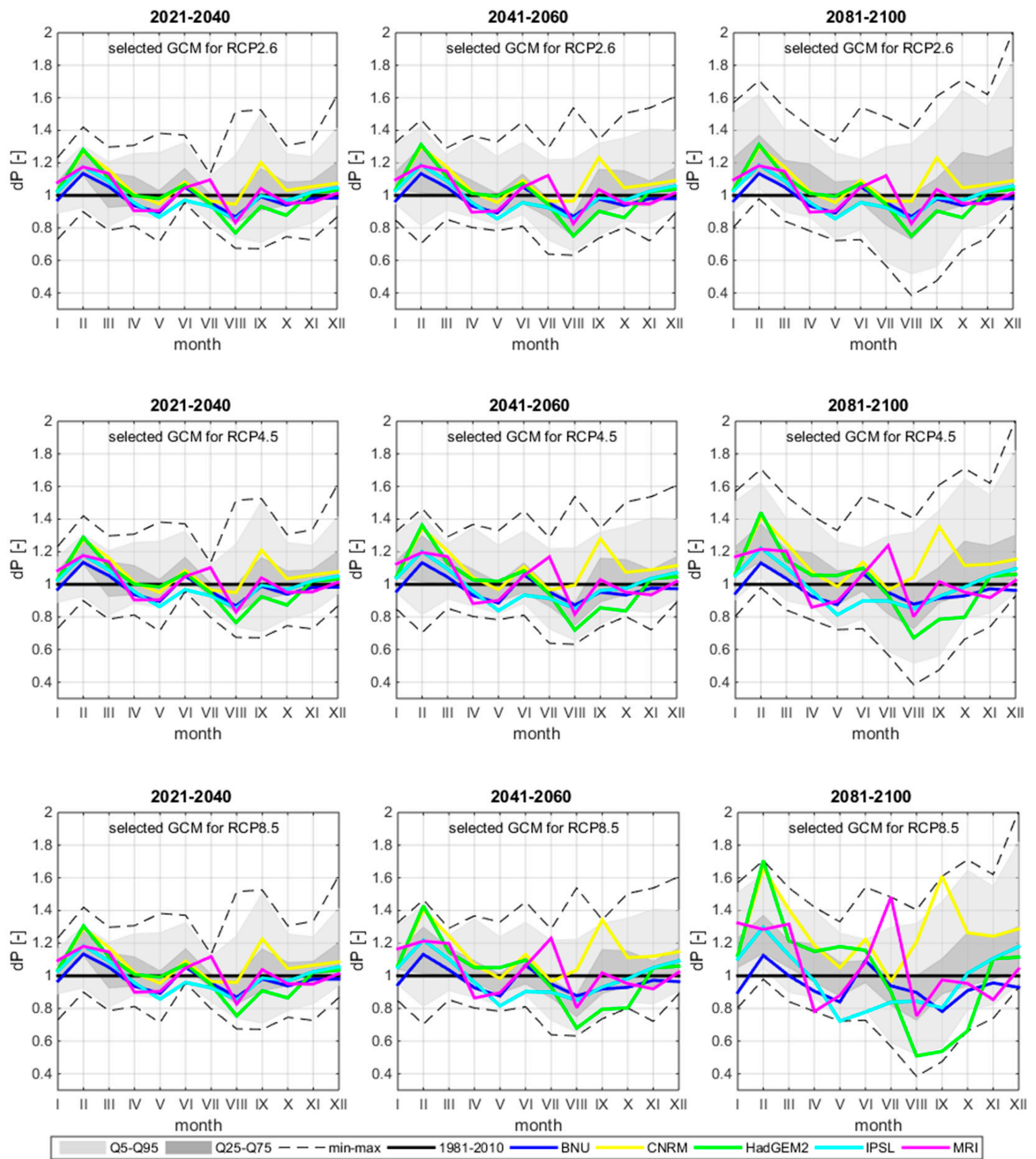

Figure 4. Uncertainty of the estimated monthly precipitation for individual time horizons (columns). The 90\% (Q5-Q95) and 50\% (Q25-Q75) confidence intervals are calculated for the ensemble of all 34 model outputs. The GCM models from the CMIP5 model for selected RCP emission scenarios (rows) are marked in color.

The resulting development of the S-Y relationship is depicted in Figure 7. For ease of navigation, all graphs display the S-Y relationship for the current climate conditions represented by the control period of 1981-2010. The graphs indicate a very wide variance of the S-Y relationship for individual climate change scenarios, which increases for distant time horizons. The variance of the storage ratio $\beta$ increases significantly for higher values of the yield ratio $\alpha$. The planned Kryry reservoir will have $\alpha=0.6$ to 0.7 and the results indicate that the variance of the required storage capacity for individual climate scenarios and time horizons is so large that the results cannot be used for responsible strategic decision making regarding the parameters of this water source. 

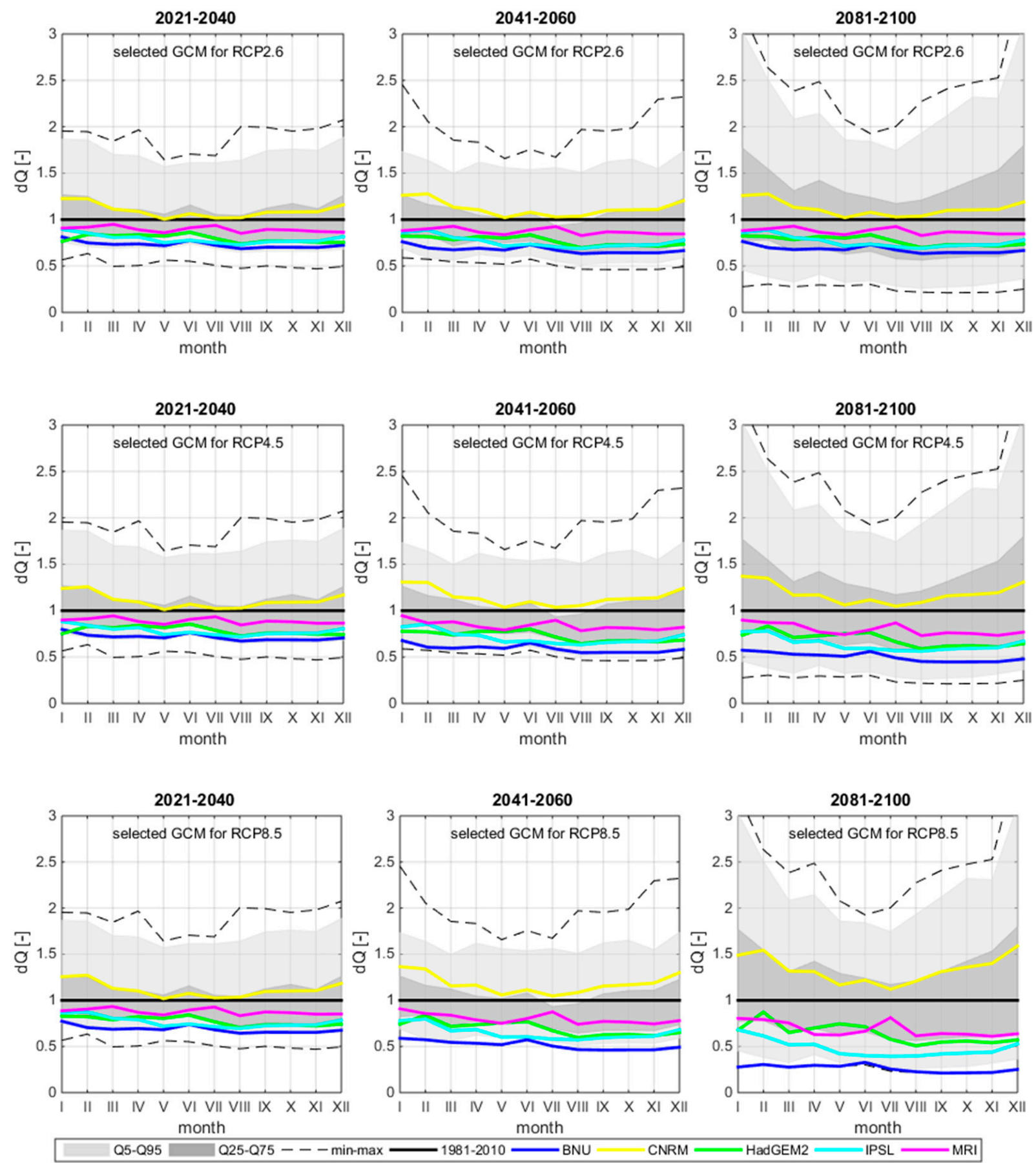

Figure 5. Uncertainty of the estimated basin outflows for individual time horizons (columns). The 90\% (Q5-Q95) and 50\% (Q25-Q75) confidence intervals are calculated for the ensemble of all 34 model outputs. The GCM models from the CMIP5 model for selected RCP emission scenarios (rows) are marked in color. 


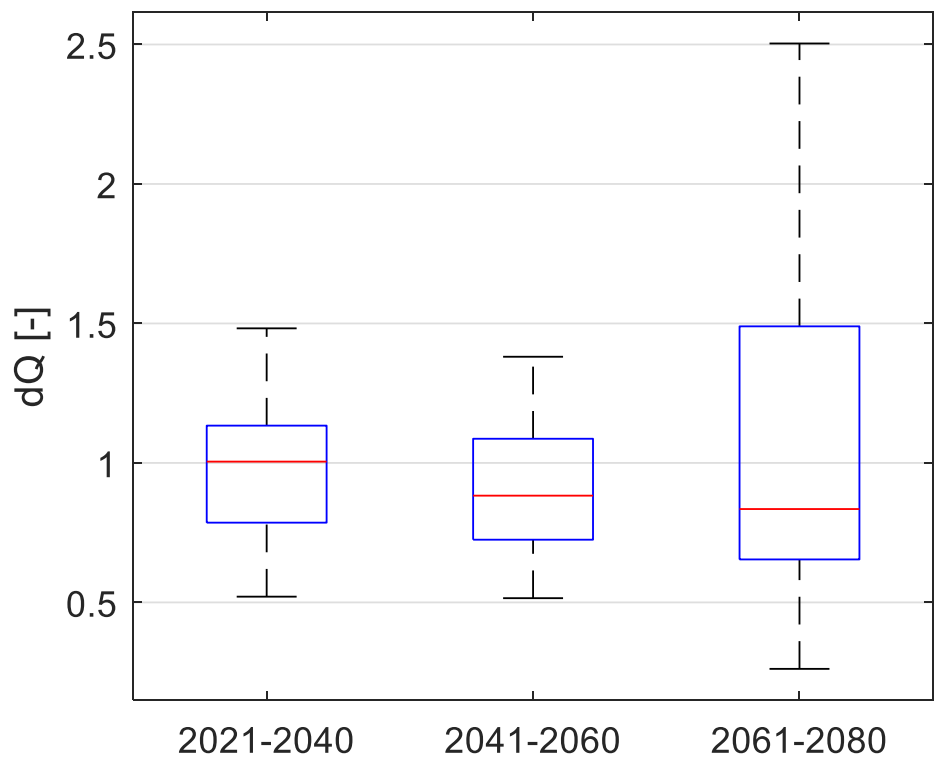

Figure 6. Boxplots of change factors of average annual flows for individual time horizons. Central red line indicates the median, and the bottom and top edges of the blue box indicate the 25 th and 75th percentiles, respectively. The whiskers extend is specified as 1.5 times the interquartile range.
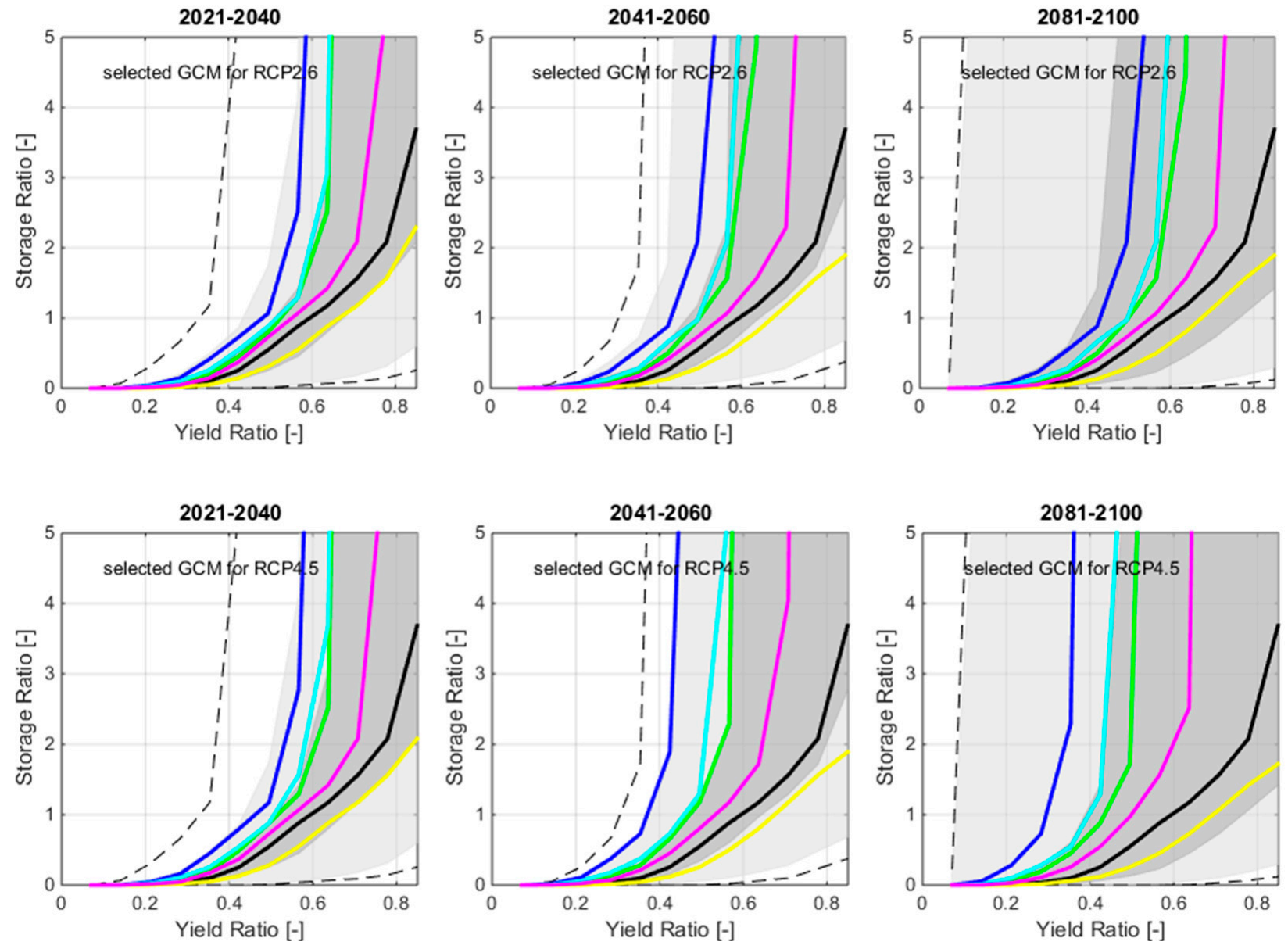

Figure 7. Cont. 

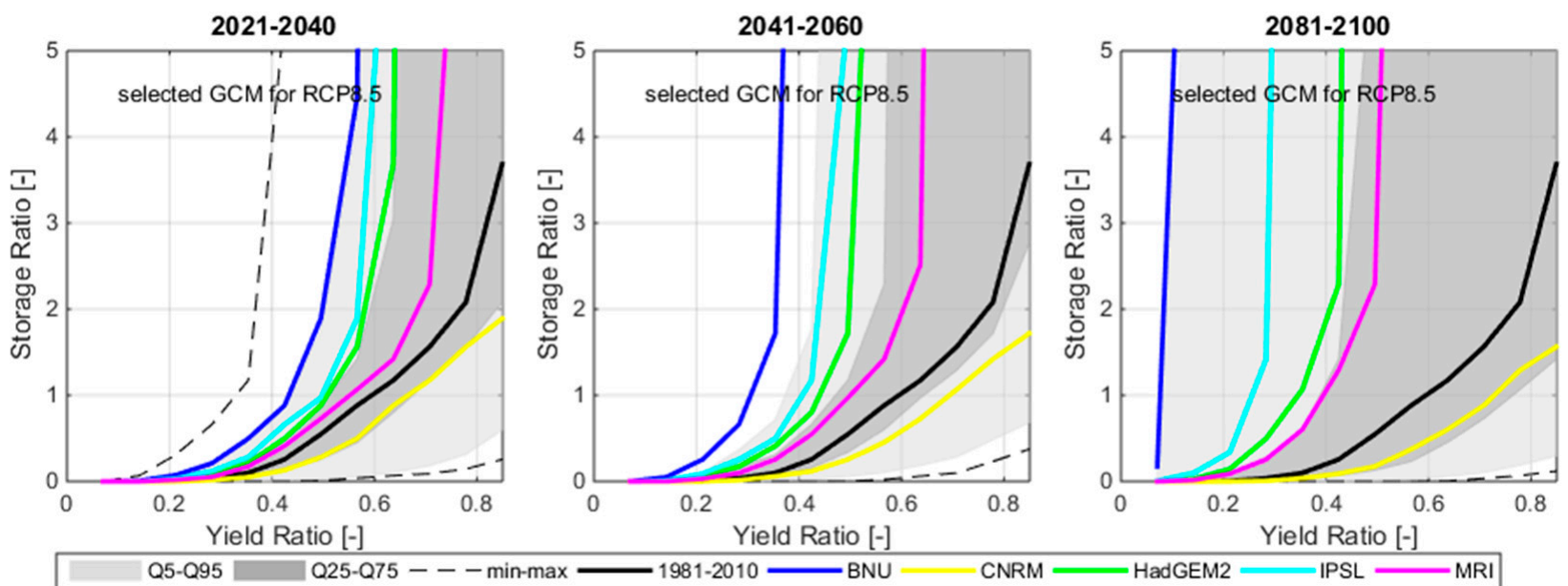

Figure 7. Uncertainty of the storage-yield relationship for individual time horizons (columns). The 90\% (Q5-Q95) and 50\% (Q25-Q75) confidence intervals are calculated for the ensemble of all 34 model outputs. The GCM models from the CMIP5 model for selected RCP emission scenarios (rows) are marked in color.

\section{Discussion}

The prepared study on the propagation of uncertainty of climate scenarios into the hydrological regime and water management balance of reservoirs showed that the results have a significant variance. It is clear that the current climate change models come with such a degree of uncertainty that they can only be used for long-term decision-making processes and for the design of strategically important construction projects to a very limited extent.

While climatologists may be content with the current results describing climate changes, hydrologists are less so and those in charge of water management have no reason to be satisfied. Due to the scope of the schematization of global and regional climate models and the size of the investigated basin of the Kryry reservoir, this approach leads to significant uncertainties in terms of estimating the hydrological balance and water supply from water reservoirs. The variance of the possible impacts of climate scenarios on the S-Y relationship is disproportionately large. The results showed that the required reservoir capacity (storage volume) varies by hundreds of percent for different climate models, which is practically useless information for strategic decision making. For this reason, a reduction in the set of climate models by excluding unlikely scenarios can be recommended. For water resources planning, we consider a variance of storage-yield relationships on the order of tens of percent to be acceptable. Such a variance of results from individual climate models can still be considered useful in water management and beneficial for strategic planning.

Some outputs of the climate models indicate that the assessed reservoirs will not be required to cover future needs, while others suggest that the reservoirs will, in fact, be insufficient. This finding matches those from the studies of Brown et al. [28], Brekke et al. [29], and Brekke et al. [30].

To objectively describe uncertainty in climate change projections in the hydrological regime and the balance of water resources, in general, it is recommended to use a simulation of multiple global climate models rather than just a single one. The used approach thus matches the recommendation of the studies of Mateus and Tullos [31], Giuliani et al. [32], and Ehsani et al. [3].

OAGCMs were useful to warn society about the ongoing climate change process, but their usefulness in the matter of adaptability is often questioned. An alternative approach for designing adaptation measures is provided by bottom-up (vulnerabilitybased) methods, which proceed in the opposite direction than top-down (scenario-led) methods [14]. At its core, this process is based on the variability of climate change and an 
assessment of the efficiency of adaptation measures on future risks. At the beginning of the whole process, a detailed list of all admissible adaptation measures is prepared followed by an assessment of the system's resilience/vulnerability to various climate conditions for individual measures or their combinations. The results can thus demonstrate whether the given measures are robust with respect to a wider range of climate projects or not. Effective adaptive measures include optimizing reservoir rule curves for future time horizons and taking advantage of the flexible water demand of users. These measures take into account the changing seasonal regime of hydrological conditions and water demands. It will be useful to further study how the redistribution of flow conditions changes during the year and whether these changes can be at least partially compensated by flexible water demand by users.

It needs to be added that if the range of climate changes is very broad, this represents a difficult decision for the person responsible for designing adaptation measures. The ranges of climate scenarios may include scenarios where no measures are needed as well as scenarios for which very costly investments are needed.

\section{Conclusions}

The strategic management of water resources was previously based on the assumption of stationarity of hydrological parameters over time. This prerequisite, however, is not currently sustainable, since changes to meteorological and hydrological parameters due to climate change are statistically significant. For strategic planning of water resources into the future, a sufficiently reliable estimate for the development of climate change along with an estimate of future water requirements and needs are crucial. A number of mathematical models are currently used to model climate change, whereas these models are characterized by a fairly large variance. This study focused on an assessment of the propagation of uncertainty in the estimate of the development of climate change into the hydrological regime and subsequently into the water management balance of water reservoirs. The study reached the following main conclusions:

1. The propagation of uncertainties in climate scenarios into the hydrological regime is significant. A prominent effect can be seen for the average annual flow ratio as well as for the distribution of flow ratio into individual parts of a year.

2. The propagation of uncertainty into the water management balance of water reservoirs was assessed using the storage-yield relationship for the selected reliability of water supply. The results of this analysis indicate that in view of the disproportionately large variance of climate scenarios, these can only be applied for strategic planning of water resources to a very limited extent.

3. Due to this reason, it is necessary to select a representative climate scenario carefully and always use multiple projections in assessments. Further research should focus on reducing the uncertainty of climate models and/or on finding an objective way to exclude irrelevant projections. In view of strategic planning of water resource capacity, it is also necessary to strive for increasing the accuracy of future demands on water resources in view of the changing climate.

4. Considering the significant uncertainties in the development of water resource capacities and the need for water in the future, it is currently advantageous to continue developing adaptation measures designed to limit the impacts of climate change. The preparation of new water reservoirs and optimization of dispatch management of water systems seem to be highly advantageous measures. Water reservoirs can not only be highly robust, but also a very effective tool towards eliminating the impacts of climate change on the reliability of water resources. 
Author Contributions: Conceptualization, V.S., P.F. and T.K.; methodology, P.F.; software, V.S. and P.F.; validation, P.F.; formal analysis, V.S., P.F. and T.K.; investigation, V.S., P.F. and T.K.; resources, V.S., P.F. and T.K.; data curation, P.F.; writing-original draft preparation, V.S., P.F. and T.K.; writingreview and editing, V.S., P.F. and T.K.; visualization, V.S., P.F. and T.K.; supervision, P.F.; project administration, V.S. and P.F.; funding acquisition, V.S. and P.F. All authors have read and agreed to the published version of the manuscript.

Funding: The article was written with support from the project "Water systems and water management in the Czech Republic in conditions of climate change", grant number SS02030027. This project is co-financed from the state budget by the Technology agency of the Czech Republic and Ministry of the Environment of the Czech Republic under the Environment for Life Programme. In the paper, some results of the project No. SGS21/107/OHK1/2T/11 of the Czech Technical University in Prague were used and this fact is also gratefully acknowledged.

Conflicts of Interest: The authors declare no conflict of interest. The funders had no role in the design of the study; in the collection, analyses, or interpretation of data; in the writing of the manuscript, or in the decision to publish the results.

\begin{tabular}{|c|c|}
\hline \\
\hline \multicolumn{2}{|c|}{$\begin{array}{l}\text { Abbreviations } \\
\text { The following abbreviations are used in this manuscript: }\end{array}$} \\
\hline LASW & General Plan of protected localities for surface water accumulation \\
\hline EU & European Union \\
\hline AOGCM & Atmosphere-Ocean General Circulation Model \\
\hline RCM & Regional Climate Model \\
\hline GCM & Global Circulation Model \\
\hline SRES & Special Report on Emissions Scenarios \\
\hline $\mathrm{RCP}$ & Representative Concentration Pathways \\
\hline RCD & Regional Climate Downscaling \\
\hline CMIP & Climate Intercomparison Project \\
\hline IPCC & Intergovernmental Panel on Climate Change \\
\hline CORDEX & Coordinated Regional Climate Downscaling Experiment \\
\hline S-Y & Storage-Yield relationship \\
\hline
\end{tabular}

\section{References}

1. Milly, P.C.; Betancourt, J.; Falkenmark, M.; Hirsch, R.M.; Kundzewicz, Z.W.; Lettenmaier, D.P.; Stouffer, R.J. Climate ChangeStationarity Is Dead: Whither Water Management? Science 2008, 319, 573-574. [CrossRef] [PubMed]

2. Watts, R.J.; Richter, B.D.; Opperman, J.J.; Bowmer, K.H. Dam Reoperation in an Era of Climate Change. Mar. Freshw. Res. 2011, 62, 321-327. [CrossRef]

3. Ehsani, N.; Vörösmarty, C.J.; Fekete, B.M.; Stakhiv, E.Z. Reservoir Operations under Climate Change: Storage Capacity Options to Mitigate Risk. J. Hydrol. 2017, 555, 435-446. [CrossRef]

4. Balvín, P.; Vizina, A.; Nesládková, M.; Blöcher, J.; Makovcová, M.; Moravec, V.; Hanel, M. Minimum Residual Flows for Catchments in the Czech Republic. Water 2021, 13, 689. [CrossRef]

5. Ministry of Agriculture of the Czech Republic. General Plan of Protected Localities for Surface Water Accumulation (In Czech); Ministry of Agriculture: Prague, Czech Republic, 2011.

6. Hari, V.; Rakovec, O.; Markonis, Y.; Hanel, M.; Kumar, R. Increased Future Occurrences of the Exceptional 2018-2019 Central European Drought under Global Warming. Sci. Rep. 2020, 10, 12207. [CrossRef] [PubMed]

7. Horton, P.; Schaefli, B.; Mezghani, A.; Hingray, B.; Musy, A. Assessment of Climate-Change Impacts on Alpine Discharge Regimes with Climate Model Uncertainty. Hydrol. Process. 2006, 20, 2091-2109. [CrossRef]

8. Beran, A.; Hanel, M.; Nesládková, M.; Vizina, A.; Vyskoč, P.; Kožín, R. Climate change impacts on water balance in Western Bohemia and options for adaptation. Water Supply 2019, 19, 323-335. [CrossRef]

9. Holtanova, E.; Kalvova, J.; Pisoft, P.; Miksovsky, J. Uncertainty in Regional Climate Model Outputs over the Czech Republic: The Role of Nested and Driving Models. Int. J. Climatol. 2013, 34, 27-35. [CrossRef]

10. Hanel, M.; Kašpárek, L.; Mrkvičková, M.; Horáček, S.; Vizina, A.; Novický, O.; Fridrichová, R. Odhad Dopadů Klimatické Změny na Hydrologickou Bilanci v ČR a Možná Adaptivní Opatření; T.G. Masaryk Water Research Institute: Prague, Czech Republic, 2011; ISBN 978-80-87402-22-1.

11. Teutschbein, C.; Seibert, J. Bias Correction of Regional Climate Model Simulations for Hydrological Climate-Change Impact Studies: Review and Evaluation of Different Methods. J. Hydrol. 2012, 456, 12-29. [CrossRef]

12. Graham, L.P.; Hagemann, S.; Jaun, S.; Beniston, M. On Interpreting Hydrological Change from Regional Climate Models. Clim. Chang. 2007, 81, 97-122. [CrossRef] 
13. Velázquez, J.A.; Schmid, J.; Ricard, S.; Muerth, M.J.; Gauvin St-Denis, B.; Minville, M.; Chaumont, D.; Caya, D.; Ludwig, R.; Turcotte, R. An Ensemble Approach to Assess Hydrological Models' Contribution to Uncertainties in the Analysis of Climate Change Impact on Water Resources. Hydrol. Earth Syst. Sci. 2013, 17, 565-578. [CrossRef]

14. Wilby, R.L.; Dessai, S. Robust Adaptation to Climate Change. Weather 2010, 65, 180-185. [CrossRef]

15. Markonis, Y.; Hanel, M.; Máca, P.; Kyselý, J.; Cook, E.R. Persistent Multi-Scale Fluctuations Shift European Hydroclimate to Its Millennial Boundaries. Nat. Commun. 2018, 9, 1767. [CrossRef] [PubMed]

16. Křeček, J.; Palán, L.; Stuchlík, E. Impacts of Land Use Policy on the Recovery of Mountain Catchments from Acidification. Land Use Policy 2019, 80, 439-448. [CrossRef]

17. Hewitt, C.D.; Griggs, D.J. Ensembles-Based Predictions of Climate Changes and Their Impacts. Eos Trans. Am. Geophys. Union 2004, 85, 566-567. [CrossRef]

18. Jacob, D.; Petersen, J.; Eggert, B.; Alias, A.; Christensen, O.B.; Bouwer, L.M.; Braun, A.; Colette, A.; Déqué, M.; Georgievski, G.; et al. EURO-CORDEX: New High-Resolution Climate Change Projections for European Impact Research. Reg. Environ. Chang. 2013, 14, 563-578. [CrossRef]

19. Štěpánek, P.; Trnka, M.; Meitner, J.; Dubrovsky, M.; Zahradníček, P.; Lhotka, O.; Sklák, P.; Kyselý, J.; Farda, A.; Semerádová, D. Expected Climatic Conditions in the Czech Republic, Part I. Change in Basic Parameters; Global Change Research Institute of the Czech Academy of Sciences (GCRI): Brno, Czech Republic, 2019.

20. Beran, A.; Hanel, M.; Nesládková, M.; Vizina, A. Increasing water resources availability under climate change. Procedia Eng. 2016, 162, 448-454. [CrossRef]

21. Svoboda, V.; Hanel, M.; Máca, P.; Kyselý, J. Projected changes of rainfall event characteristics for the Czech Republic. J. Hydrol. Hydromech. 2016, 64, 415-425. [CrossRef]

22. Hanel, M.; Mrkvičková, M.; Máca, P.; Vizina, A.; Pech, P. Evaluation of simple statistical downscaling methods for monthly regional climate model simulations with respect to the estimated changes in runoff in the Czech Republic. Water Resour. Manag. 2013, 27, 5261-5279. [CrossRef]

23. Hanel, M.; Kožín, R.; Heřmanovský, M.; Roub, R. An R package for assessment of statistical downscaling methods for hydrological climate change impact studies. Environ. Model. Softw. 2017, 95, 22-28. [CrossRef]

24. Hanel, M.; Vizina, A.; Maca, P.; Pavlasek, J. A multi-model assessment of climate change impact on hydrological regime in the Czech Republic. J. Hydrol. Hydromech. 2012, 60, 152-161. [CrossRef]

25. Ladislav, K. Regional Study on Impacts of Climate Change on Hydrological Conditions in the Czech Republic; T.G. Masaryk Water Research Institute: Prague, Czech Republic, 1998.

26. Tallaksen, L.M.; van Lanen, H.A.J. Hydrological Drought: Processes and Estimation Methods for Streamflow and Groundwater; Elsevier: Amsterdam, The Netherlands, 2004.

27. Koutsoyiannis, D. Reliability Concepts in Reservoir Design. In Water Encyclopedia; Lehr, J.H., Keeley, J., Eds.; Wiley-Interscience: New York, NY, USA, 2005; p. 4. [CrossRef]

28. Brown, C.; Ghile, Y.; Laverty, M.; Li, K. Decision Scaling: Linking Bottom-up Vulnerability Analysis with Climate Projections in the Water Sector. Water Resour. Res. 2012, 48, W09537:1-W09537:12. [CrossRef]

29. Brekke, L.D.; Dettinger, M.D.; Maurer, E.P.; Anderson, M. Significance of Model Credibility in Estimating Climate Projection Distributions for Regional Hydroclimatological Risk Assessments. Clim. Chang. 2008, 89, 371-394. [CrossRef]

30. Brekke, L.D.; Maurer, E.P.; Anderson, J.D.; Dettinger, M.D.; Townsley, E.S.; Harrison, A.; Pruitt, T. Assessing Reservoir Operations Risk under Climate Change. Water Resour. Res. 2009, 45, W04411:1-W04411:16. [CrossRef]

31. Mateus, M.C.; Tullos, D. Reliability, Sensitivity, and Vulnerability of Reservoir Operations under Climate Change. J. Water Resour. Plan. Manag. 2017, 143, 04016085. [CrossRef]

32. Giuliani, M.; Anghileri, D.; Castelletti, A.; Vu, P.N.; Soncini-Sessa, R. Large Storage Operations under Climate Change: Expanding Uncertainties and Evolving Tradeoffs. Environ. Res. Lett. 2016, 11, 035009. [CrossRef] 